\title{
Európa egyesítése vagy az Európa feletti uralom?
}

\section{Adalékok az Európa jövőjéről szóló konferenciához}

\author{
Europe: Unification of Domination? \\ Some Thoughts with Regards to the Conference \\ of the Future of Europe
}

A történelem folyamán számos kísérletet lehetett látni az Európa feletti dominancia megszerzésére. Bár voltak időszakok, amikor egyik-másik nemzet idegen elnyomás alatt élt, de az Európa egésze feletti katonai hatalom megszerzése soha senkinek sem sikerült. Az európai integráció történetét is kettôsség jellemzi: egyfelöl szupranacionális törekvések, másfelöl szabad nemzetek szövetségének elképzelése küzd egymással. Az európai gazdasági egységesülés hosszú évtizedekre prosperitást biztosított, ugyanakkor Európa az utóbbi bő tíz esztendőben súlyos válságidőszakot élt át. Az európai egység válaszút előtt áll. Az Európa Jövőjéről szóló Konferencia bár keretet nyújt az önreflexióhoz, de kérdéses, hogy képes lesz-e az egymástól eltérö nézöpontok mellett reális végkövetkeztetéseket megfogalmazni. Európa egysége nem jelentheti az Európa és annak országai fölötti uralmat. Európa szabad országainak integrációja csak akkor lehet sikeres, ha annak mottója megvalósul: Egység a sokszínüségben.

Kulcsszavak: Európa, európai integráció, Konferencia Európa Jövőjéről, szuverenitás, szupranacionalitás

Throughout the history of Europe, there were several attempts for its domination. Even though there were periods when certain nations lived under the oppression of foreign powers, no one could acquire military dominance over the whole continent. The history of the European integration was marked by the same dilemma: there are efforts to create a supranational entity, which are in contrast with the principle of 
the alliance of free European nations. The European economic integration brought unprecedented prosperity; however, the European Union underwent a serious crisis period in the last decade. The European unification process is at a crossroad. The Conference on the Future of Europe might offer a forum for true reflection, but it is questionable whether it can deliver realistic results. The unity of Europe cannot mean domination over Europe and the countries of Europe. The integration of the free European countries can only be successful if its motto, unity in diversity comes true.

Keywords: Europe, European integration, Conference on the Future of Europe, sovereignty, supranational

\section{Európa egysége történeti távlatokból}

Amikor Európa egységéről gondolkodunk, érdemes egy rövid időutazást is tenni. Az elmúlt évszázadokban a kérdés az volt, hogy ki, hogyan tud akár birodalmi gondolkodás miatt is Európa fölött hatalmat gyakorolni. Példaként említhető a Római Birodalom, amely katonai erejével akarva-akaratlanul is Európa nagy része felett európai birodalmat tudott kiépíteni. A római jog pedig hozzájárult az európai közös jogi kultúra megteremtéséhez. De ahogy nőtt a római birodalom területi mérete, hatalma ehhez képest inkább gyengült, majd hanyatlásnak indult. Később Nagy Károly vonta uralkodása alá Európa jelentős részét, kiterjedt államszervezetet alapított, egységes pénzrendszere fellendítette a kereskedelmet, Európa nagy részén megszilárdult a kereszténység. Később V. Károly német-római császár birodalmára mondták, hogy „birodalmában sohasem nyugszik le a Nap”. A birodalmak azonban csak ideig-óráig tudtak fennmaradni, Európa népeinek egységesítése soha nem vezetett eredményre.

A vesztfáliai békeszerződést követőn létrejött nemzetállamok már hatalmi egyensúlyra törekedtek Európában, ennek érdekében különböző szövetségeket kötöttek egymással az uralkodók. A szövetségek gyakorta vívtak egymással háborúkat, ezáltal Európa sokszor katonai hadszíntérré változott. Ennek legjobb példája Napóleon, aki egészen Moszkváig vezette csapatait annak érdekében, hogy uralma alá vonja Európát. A napóleoni időszakban elfogadott polgári és büntető törvénykönyvek, valamint közigazgatási rendszer azonban a latin országok számára modellként szolgált, így nem véletlen, hogy például az Államtanács intézményét számos európai ország bevezette. $\mathrm{Az}$ egyes országok - a katonai konfliktusok ellenére - hatással voltak egymásra, így például a jog területén ma is a hasonló jegyek alapján megkülönböztetjük a common law, a latin vagy germán jogcsalád befolyása alatt álló országokat. A szellemi irányzatok is hatottak Európa népeire, gondoljunk csak a kereszténység felvételére, a reneszánszra, a humanizmusra, vagy a 18. században a felvilágosodásra. A 19. században pedig megszületik a német és az olasz egység, létrejön az egységes Olaszország és Németország. Európában a politikai jogok megszerzését követően a gazdasági, szociális és kulturális jogok megszerzése lett a cél.

A 20. század rémtettei két diktátor nevéhez fűződnek. Hitler a német birodalomirányító hatalmával, Sztálin pedig Moszkva irányításával akart Európa feletti hatalmat szerezni. Mindkettőjük vállalkozása a fegyverek erején nyugodott. Hitler a fajelmélet, 
Sztálin a kommunista ideológia eszméivel kívánta uralma alá vonni Európát. Hitler néhány év alatt bukott el, ezzel szemben a sztálini rendszer, különböző kommunista vezetők irányítása alatt a múlt század végéig fennmaradt. A diktatúrák tagadták a pluralizmust, egy kizárólagos ideológia mellett kívántak érvényt szerezni hatalmi törekvéseiknek.

A történelem azt bizonyította, hogy az Európa feletti katonai hatalom megszerzése soha senkinek sem sikerült. Voltak időszakok, amikor egyik-másik nemzet idegen elnyomás alatt élt, de a szabadság iránti vágy előbb-utóbb mindig győzedelmeskedett. Mindazonáltal a szellemi egymásra hatás a jogban, filozófiában, építészetben és az élet területén mindvégig kimutatható.

\section{Az Osztrák-Magyar Monarchia mint integrációs kísérlet}

Mindennemű hiányosságai ellenére is a 19. század egyik legjelentősebb integrációs kísérletének is tekinthető az Osztrák-Magyar Monarchia. A kül- és hadügy, valamint az ezek fedezetéül szolgáló pénzügyek közös miniszterek alá tartoztak, akik nem a 60-60 fős közös parlamenti delegációnak, hanem közvetlenül az uralkodónak tartoztak felelősséggel. Az eltérő kultúrájú nemzetek gazdasági fellendülését biztosítani tudta a birodalmi karakterű Monarchia. Ekkor épültek a legfontosabb középületek, pályaudvarok, színházak, banképületek, kávéházak, fürdőhelyek és megannyi más fontos épület. Sokan a boldog békeidők korszakának tartották a Monarchia időszakát. A vámközösség gazdasági érdekközösséget is létrehozott a Monarchia területi egységei között. Ekkor fogadták el azokat a törvényeket és intézményeket, amelyeket ma is számon tartunk és megbecsülünk. A Monarchia azonban nem tudott valódi föderációvá fejlődni, ennek egyik oka, hogy a két ország politikai vezetői nem tudtak mit kezdeni a nemzetiségek önállósodási törekvéseivel. A túlzott Bécs-központúság irigységet váltott ki Budapesten, Prágában és más nagyvárosokban, az egyenjogúság érzetének hiánya a Monarchia belső kohézióját gyengítette. Az eltérő fejlettségű és mentalitású régiók összefogásának intézményi és kulturális (nemzetiségi) akadályai is voltak, így felbomlása - nem csak a világháború elvesztése folytán - sorsszerúnek is tekinthető. Mindazonáltal a Monarchia egykori problémája üzenet a mai Európai Uniót föderatív egységnek elképzelők számára, a különböző kultúrájú, történetű nemzetek egyesítésének megvannak a határai. Ezt mi, magyarok tudjuk a legjobban.

\section{Az európai integráció mint az európai egység szimbóluma}

Az európai egység gondolata a II. világháború borzalmait és szenvedéseit követően az akkor szabad országok vezetői beszédeiben természetszerúen jelent meg. A törésvonalak azonban már korán kialakultak, Winston Churchill világképe lényegesen eltért 
a Robert Schuman vagy Jean Monnet által elképzelt szupranacionális világképtől. Az európai integráció alapító országai ez utóbbi irányvonalat képviselték és határozták el a szabad belső piac kialakítását, közös szupranacionális intézmények létrehozása mellett. Az alapító atyák célja a béke megőrzése mellett a szubszidiaritás elve alapján müködő, szabad gazdasági együttmüködésre koncentráló, egyre szorosabban együttműködő európai térség létrehozása volt. A szupranacionalitás érvényre juttatását az európai intézmények által elfogadott közös jog biztosítja, amelynek védelmezője és aktivista alakítója az Európai Bíróság. Noha az európai integrációval szembeni bizalmatlanság erősen megjelent Charles de Gaulle nézeteiben, annak fejlődését ő sem tudta megakadályozni. Halálát követően pedig egymás után csatlakoztak a szabad vagy szabaddá váló országok a közös piac intézményrendszeréhez. A gazdasági integrációt kiegészítette a transzatlanti kapcsolatok kiépítése, amely a NATO-n keresztül biztosította Európa szabad országainak katonai védelmét. 1950-ben elfogadták az Emberi Jogok Európai Egyezményét (EJEE), amelynek keretében az Európai Emberi Jogi Bíróság felügyeletet kapott az EJEE tiszteletben tartása érdekében. A II. világháborút követően tehát egy komoly szupranacionális, nemzetközi intézményi hálózat jött létre a világban (például az ENSZ) és Európában is, amely az európai egységet kívánta biztosítani a vasfüggöny mögött elhelyezkedő, szovjet megszállás alatt álló országokkal szemben.

A vasfüggöny lebontásáig Európa két részre szakadt: a demokrácia és a diktatúra térségére. Európa szabad országainak integrációját a kommunizmussal szembeni félelem is erősítette, a közös ellenséggel szemben az integráció erőt tudott sugározni. A demokrácia országaiban a piacgazdaságra, a közös piac szabadságára helyeződött a hangsúly, majd a későbbiekben újabb és újabb területeket kezdett érinteni az integráció.

Az európai egység gazdasági sikerei vonzók voltak a szegénységben élő kommunista országok számára, és a kialakult szabadságérzet óhatatlanul is a Nyugathoz való tartozást, igazodást idézte elő a volt szocialista országokban. Európa politikai egysége elérhetőnek tűnt. Az 1992-ben aláírt és 1993-ban hatályba lépett maastrichti szerződés már célul tủzhette a gazdasági integráción túlmutató politikai integrációt is. Mindezen idő alatt a csatlakozásra váró országok piacaikat megnyitották, a tőke szabad áramlását idejekorán biztosították. Mindez magával hozhatta ezen országok fejlődését, bár az árnyoldalak is hamar jelentkeztek (át nem gondolt privatizációk, stratégiai ágazatok feletti kontroll elvesztése, piacvesztés stb.). Európa gazdasági egyesítése viszont nem tudta megoldani Európa szellemi egyesítését. Már az EU-hoz történő csatlakozás kezdetén a nyugati közvélemény lengyel vízvezetékszerelőkkel rémisztgette a volt szocialista országokkal szemben egyébként is averzióval élő polgárait, és hamar kiütközött az, hogy a 40 év vasfüggöny Európa nemzetei között törésvonalakat hozott létre. A nyugateurópai politikusok elkezdték patikamérlegen mérni a jogállamiság kérdését, és mindig a közép- és kelet-európai országokat találták meg kritikáikkal, különösen akkor, ha az adott országban jobboldali kormány alakulhatott meg.

Nyugat-Európa társadalma az 1970-es évekre egyébként is átalakult, szekularizálódott. A hagyományos családmodell szerepét vesztette, a volt gyarmatokról történt tömeges bevándorlás következtében párhuzamos társadalmak kezdtek kialakulni, a nemzethez tartozás eszméje háttérbe szorult, és nem mellesleg az olajválság is megtörte az addigi, a II. világháborút követő töretlen gazdasági prosperitást. A szabaddá vált volt szocialista országok ezzel szemben jobban ragaszkodnak a nemzetállami 
modellhez, a nemzeti érzés, a nemzettudat ugyanis fontos szerepet játszott a rendszerváltozáskor, és az európai integrációban való részvétel számukra nem jelenti az önálló államiság elvetését. A közép- és kelet-európai országok nem kívánták egy az egyben átvenni a nyugat-európai társadalmi modellt, és ma is jobban ragaszkodnak hagyományosnak tekinthető fogalmakhoz (család, házasság, közösség). E térség országai nem kívánnak osztozni a nyugati volt gyarmattartó országok gazdasági prosperitásának egy részét megalapozó, illetve eddigi politikájából eredő bevándorlási hullámával, ezzel szemben erős szolidaritást éreznek a Nyugat-Balkán országaival. A nyugati országok saját problémáikat érzékelve, egyfajta bűnbakként tekintenek a volt szocialista országokra, önzéssel, a szolidaritás hiányával vádolva, a jogállamisági, közös európai értékek veszélyeztetőinek bemutatva őket.

\section{Merre tovább európai integráció?}

Válaszút előtt állunk. Eredmények és buktatók sora kíséri az elmúlt évtizedeket. Grandiózus elképzelések, de gyakran csak szerény eredmények. Számos ellentmondás kíséri a fejlődést. Egy a politikai unió irányába mozduló európai integráció, másrészről szellemiségében megosztott európai közösség. A politikai unió irányába tett lépések látványosnak is mondhatók: közös határvédelem, közös európai hadsereg, európai ügyészség, hogy csak a napirenden lévő ügyek közül említsünk. Újabb és újabb európai ügynökségek jönnek létre, ami jól mutatja az uniós hatáskör folyamatos bővülését, a központosítási törekvéseket. Létrejött egy brüsszeli buborék, mondhatni integrációs gőg, egyfajta felsőbbrendűségi tudat szemben a nemzeti intézményekkel. A központosítást azonban nem kísérte és nem kíséri szellemi kohézió, a tagállamok polgárainak egy jelentősnek mondható hányada bizalmatlanul figyeli a fejleményeket. A Brexit jól példázza azt, hogy egy tagállam polgárai elfordultak az Európai Uniótól, a brit polgárok többsége nemet mondott a tagságra. Ettől, valamint a kritikus hangoktól talán meg is rémülve az európai uniós mainstream az európai egység veszélyeztetésére hivatkozással úgy vélte, hogy meg kell rázni a harangokat, az európai polgárokkal intenzív párbeszédet kell folytatni. Ezt célozza az Európa jövőjéről szóló idén induló konferencia. Az már most jól kódolható, hogy a konferenciának különös jelentősége lesz. Nincs kétség afelől, hogy a föderalisták versus nemzetállamban vagy eurorealista gondolkodók eltérő nézetei összecsapásának lehetünk majd szem- és fültanúi.

A különböző pártcsaládokhoz tartozó föderalisták úgy vélik, hogy Európa egységét csak a központosítással, az európai intézmények hatalmának további megerősítése útján lehet elérni. Erősebb Európai Parlamentre van szükség, a képviselőket részben transznacionális listán kell megválasztani, be kell vezetni a csúcsjelölti rendszert, valódi európai kormányra van szükség, az európai biztosoknak miniszteri megnevezést kell kapniuk, a tagállamokat képviselő tanácsi formáció legyen az Európai Parlament második kamarája, az állam- és kormányfőket képviselő Európai Tanács jogosítványait korlátozni szükséges. A tagállamok szerepét csökkenteni kell, felesleges fékjei az európai megoldások elfogadásának és érvényre juttatásának. Ezért a döntéshozatali mechanizmusnál általánossá kell tenni a többségi döntéshozatalt, megakadályozandó, hogy akár egy tagállam is vétójogával élhessen. A nemzeti érdek helyett összeurópai 
érdekekre kell törekedni. Szerintük az európai jog elsőbbsége abszolút jellegű, a nemzeti alkotmányok nem képezhetnek korlátot. A föderalisták olyan valódi európai polgárokat képzelnek el, akiknél az európai identitás, az európai ügyek iránti szolidaritás dominál. A churchilli értelemben vett Európai Egyesült Államok víziója szükségszerűen magában foglalja a nyitott társadalom és az ideológiailag meghatározott tartalmú jogállam iránt elkötelezett európai démoszt, amelyben a fejlett civil társadalom meghatározó szerepet játszik. A föderalisták mindazon politikai erőket, amelyek ezen eszméket támogatják, Európa-párti erőknek nevezik, szemben azokkal, akik a nemzetállamra épülő integrációt képviselik. Ők az Európa-ellenes erők a zsargonukban.

A nemzetállamok szerepét megtestesítő erők ezzel szemben kizárnak minden olyan intézményi és részben hatásköri változtatást, amelyek a tagállamok hatáskörének a csökkentését eredményezik. Állítják, a lopakodó hatáskörgyakorlással az európai intézmények jogtalanul és demokratikus felhatalmazás nélkül vesznek el hatásköröket a tagállamoktól, mindezt nem egyszer az Európai Bíróság hathatós segítségével. Az osztott hatáskört az Európai Unió kiüresíti, így a tagállamok döntési jogosítványai folyamatosan csökkennek. Véleményük szerint tehát az európai intézmények demokratikus múködése erősen kétséges. Az Európai Parlament - annak ellenére, hogy tagjait közvetlenül választják meg - nem a népszuverenitás letéteményese, európai nép nem, csak európai népek és nemzetek léteznek. Nemzeti delegációk vannak jelen az Európai Parlamentben, az európai politikai pártok csak laza pártszövetséget képeznek.

Az e nézetet vallók gyakorta hívják elő a nemzeti alkotmánybíróságok olyan döntéseit, amelyekben a nemzeti alkotmányokon épülő európai integrációt hangsúlyozzák. Azaz az Európai Uniónak a hatáskör-átruházás elvén és a tagállamok alkotmányos identitásának tiszteletben tartásán kell alapulnia. Az Európai Unióban való részvétel nem válhat egyenlővé egy európai föderális államban való részvétellel, ehhez ugyanis az Uniót alkotó népek hozzájárulására lenne szükség. Az átadott hatáskörök visszavonhatók és az Unióból való kilépés is lehetséges. Az elmúlt tíz esztendőben mindenesetre jól kimutatható, hogy az alkotmányos identitás fogalma milyen mértékben vált az alkotmányjogi szakirodalomban vita tárgyává. Nyilvánvaló, hogy a föderalisták szemében az alkotmányos önazonosság egy, az általuk elképzelt európai egységet veszélyeztető fogalom, ugyanakkor a tagállamok jogosítványait védelmezők számára az pajzsként fogható fel.

Az eurorealisták szemben az előző két nézettel egyfajta hidat kívánnak képezni. Egyaránt fontos számukra az európai és a tagállami szuverenitás. Az „európai szuverenitás” alatt azt értik, hogy az európai kontinensnek versenyképesnek kell lennie a kontinensek versenyében, így Európa például a könnyü-, a nehézipar vagy a digitalizáció területén nem függhet más kontinensek szereplőitől. Európának erőt kell mutatnia és vonzónak kell lennie. Ezt a vonzerőt elsősorban a szomszédos országok irányába kell megmutatni, ezért számukra kiemelt jelentősége van a szomszédságpolitikának. Nem értenek egyet a folyamatos uniós hatáskörbővítéssel, úgy vélik, hogy esetről esetre lehet megítélni, hogy hol kell az Európai Unió erejét növelni, és mely területek azok, amelyeknél a hatáskörök akár vissza is adhatók a tagállamok számára. Nem zárnak ki bizonyos intézményi reformokat annak érdekében, hogy az Unió hatékonyabb módon müködjön, azonban nem támogatják az Európai Egyesült Államok képét. Az eurorealisták számára fontosak a nemzeti és keresztény gyökerek, azokat nem kívánják sutba 
dobni, viszont a globalizálódó világban az „európai szuverenitás” megőrzése érdekében készek a mélyebb együttműködés kialakítására.

Az európai egység válaszút előtt áll. Ennek egyik fóruma a 2021. május 9-én indult és jövő év tavaszáig tartó Európa jövőjéről szóló konferencia. Kérdés, hogy a konferencia képes lesz-e arra, hogy a nagyon eltérő nézőpontok mellett reális végkövetkeztetéseket fogalmazzon meg, vagy egyes politikai erők arra kívánják felhasználni azt, hogy nézeteiket általánosként tüntessék fel. Félő, hogy ebben az esetben az európai szellemi egység még törékenyebbé fog válni. Aggodalomra van ok. Sok függ a konferencia irányítóitól. Ha csak egyfajta hangot akarnak meghallani, akkor a konferencia nem lesz sikeres. Nem elegendő a ma még bizonytalan összetételű civil agorát Strasbourgban vagy más európai intézmény székhelyén megszervezni. Meg kell hallani a nemzeti intézmények, így különösen a nemzeti parlamentek hangját is. Az ő véleményük ismerete nélkül nem lehet megállapításokat tenni, már csak a démosz uralma elv alapján sem. Ugyanis a nemzeti parlamentek a népszuverenitás letéteményesei, a nemzeti parlamenti képviselők állnak legközvetlenebb kapcsolatban a választókkal, ők azok, akik hiteles véleményeket tudnak megfogalmazni arról, hogy mit gondolnak a polgárok az európai építkezésről. Nem árt emlékezni arra is, hogy 2005-ben az Európai Konvent által kidolgozott Alkotmányos Szerződést az Európai Unió két alapító tagja, Franciaország és Hollandia népszavazás útján utasította el.

$\mathrm{A} z$ Európai Uniónak értelme és számos eredménye van. De az európai egység csak akkor tud értékes lenni, amennyiben az Unió tiszteletben tartja Európa nemzeteinek, népeinek sokszínűségét, eltérő történelmi hagyományait. Észak-, Dél-, Nyugat-, Középés Kelet-Európa országainak polgárai érdekeltek a békében élő kontinens felvirágoztatásában. Európa öreg kontinens. A történelem bebizonyította, hogy csak ideig-óráig vonható uralom alá. Európa egysége nem jelentheti az Európa (és annak országai) fölötti uralmat. Európa szabad országainak integrációja csak akkor lehet sikeres, ha annak mottója megvalósul: Egység a sokszínűségben. 